\title{
Two-way Selections for Survival Time of Allografts in Chickens
}

\author{
Yoshio Y Amamoto and Ikuo OKada \\ Faculty of Applied Biological Science, Hiroshima University, \\ Higashi-Hirosima 724, Japan
}

\begin{abstract}
Two-way selection for the survival time of allografts in chickens was carried out over eight generations. The foundation stocks used for selection were composed of only $B^{l l} B^{l l}$ genotype at the major histocompatibility $B$ locus. The graft from the long survival line was used for testing the survival time of allografts for both long (L) and short (S) survival lines.

The selection was effective in the $L$ line, but not necessarily effective in the $S$ line. The differences between the $\mathrm{L}$ and $\mathrm{S}$ lines increased with each successive generation of selection except with the second generation. The realized heritability was comparatively high, with a mean value of 0.334 . At the seventh generation of selection, the proportion of survival allografts in the L line was 48.5 $\%$ at 90 days after transplantation and that in the $\mathrm{S}$ line was zero. However, when another line (GVHR line) was used as donor line, the proportions of survival grafts in the $\mathrm{L}$ and $\mathrm{S}$ lines were only 12.5 and $4.0 \%$, respectively.

In comparison of graft-versus-host competence at the seventh generation of selection, the mean splenomegaly index of the L line was significantly larger than that of the $\mathrm{S}$ line. The immune response to sheep red blood cells was also compared in the $\mathrm{L}$ and $\mathrm{S}$ lines at the fifth generation of selection. No line difference was found.
\end{abstract}

(Jpn. Poult. Sci., $27: 337-345,1990)$

Key words : histocompatibility, wattle grafting, skin grafting, selection, graftversus-host reaction

\section{Introduction}

The strong histocompatibility effect of the $B$ blood group locus in chickens had been shown by Schierman and NoRDskog ${ }^{1}$. Their finding has been confirmed later by other investigators ${ }^{2,3}$. The existence of minor histocompatibility systems in chickens has been also found by several investigators ${ }^{4-7)}$. On the other hand, HÁLA ${ }^{8)}$ estimated the existence of 5 to 9 histocompatibility loci on the basis of skin graft rejection exchanged between birds of the $F_{1}$ generation of inbred lines, although individual loci was not yet identified. In non-inbred lines of chickens, some of histocompatibility loci tended to be segregating. Therefore, even when the major histocompatibility $B$ genotypes of donor and recipient birds were compatible, the survival time of allografts still varied due to the effects of minor histocompatibility antigens $^{9,10)}$.

The present investigations were concerned with selection for the survival time of allografts in order to establish a pair of lines which have a same allele at the major

Received Dec. 4, 1989 
histocompatibility locus but differ in alleles at other minor histocompatibility loci.

\section{Materials and Methods}

\section{Chickens}

The foundation stocks used in the selection experiment were obtained from the $\mathrm{N}$ strain of White Leghorn kept by random mating at the Animal Breeding Laboratory of Hiroshima University. The details of the strain have been previously described by OKADA and MiKAMI ${ }^{11}$. The foundation stocks were homozygous for the $B^{11}$ allele at the major histocompatibility locus.

To test the selection effects on the graft survival, a line homozygous for $B^{11}$, which was established by selection for graft-versus-host reaction (GVHR) competence, was used as a donor line at the seventh generation. The details of the lines have been already given by OKADA and Mikami ${ }^{11}$.

\section{Selection procedures}

Two-way selection for the mean survival time of grafts was carried out. For the initial four generations of selection the wattle was used for grafting, because in wattle grafting it is easier to find the sign of rejection for the short period of observation. However, prolongation of survival time made it difficult to determine exactly the rejection time. Therefore, after the fifth generation, grafts were changed to the skin. Since the skin was grafted in reverse direction, the rejection time was easily determined by observing the growing reversed feathers for the long survival time.

At the zero generation, grafts were obtained from chickens of the base population. From the next generation, grafts for both long (L) and short (S) survival lines were obtained from chickens of the $\mathrm{L}$ line. The numbers of chikens tested and selected are listed in Table 1.

\section{Transplantation}

Grafts used for transplantation were the wattle or skin. The wattle was transplanted by the method described by PuRchase ${ }^{12)}$ and the skin was grafted according to the method of Polley et al. ${ }^{13)}$, with a minor changes. A wattle graft was obtained from about two month-old male chicken and a skin graft from two week-old chicks. Two week-old chicks were used as recipients for grafting. The wattle of donor chicken was cleaned with $70 \%$ alcohol and clamped with a long jawed hemostat and the wattle was amputated near the hemostat. The amputated wattle was cut into a single thickness of wattle graft (about $5 \times 8 \mathrm{~mm}$ ). For skin grafting, the down was removed from the backs of donor and recipients, then anesthetized with ethyl ether. A full thickness of skin graft (about $5 \times 8 \mathrm{~mm}$ ) was removed. Generally, each chick received one autograft and three test grafts. The mean survival time of the three grafts was used as the graft survival time of the test chick.

Transplanted grafts were scored daily from the fifth day after grafting on. A macroscopic scoring method similar to that of PoLley et al. ${ }^{13)}$ was used to determine the time of graft rejection. In case of an acute rejection, the survival end-point of grafts was taken as the day on which the graft no longer blanched on digital pressure, and in case of a chronic type, the end-point was taken as the day on which a shiny 
Table 1. Numbers of birds tested and selected per generation

\begin{tabular}{|c|c|c|c|c|c|}
\hline \multirow{2}{*}{ Generation } & \multirow{2}{*}{ Line $^{11}$} & \multicolumn{2}{|c|}{$\begin{array}{l}\text { Number of } \\
\text { birds tested }\end{array}$} & \multicolumn{2}{|c|}{$\begin{array}{l}\text { Number of } \\
\text { birds selected }\end{array}$} \\
\hline & & Male & Female & Male & Female \\
\hline \multirow[t]{2}{*}{0} & $\mathrm{~L}$ & 17 & 22 & 8 & 9 \\
\hline & $\mathrm{S}$ & 17 & 22 & 7 & 8 \\
\hline \multirow[t]{2}{*}{1} & $\mathrm{~L}$ & 9 & 11 & 4 & 4 \\
\hline & $\mathrm{S}$ & 10 & 10 & 4 & 6 \\
\hline \multirow[t]{2}{*}{2} & $L$ & 10 & 9 & 4 & 5 \\
\hline & $S$ & 10 & 10 & 4 & 6 \\
\hline \multirow[t]{2}{*}{3} & $\mathrm{~L}$ & 8 & 12 & 4 & 6 \\
\hline & $\mathrm{S}$ & 9 & 10 & 4 & 5 \\
\hline \multirow[t]{2}{*}{4} & $\mathrm{~L}$ & 9 & 11 & 5 & 6 \\
\hline & $\mathrm{S}$ & 9 & 10 & 5 & 6 \\
\hline \multirow[t]{2}{*}{5} & $\mathrm{~L}$ & 16 & 17 & 6 & 8 \\
\hline & $\mathrm{S}$ & 16 & 16 & 8 & 9 \\
\hline \multirow[t]{2}{*}{6} & $\mathrm{~L}$ & 23 & 20 & 6 & 9 \\
\hline & $\mathrm{S}$ & 16 & 23 & 6 & 9 \\
\hline \multirow[t]{2}{*}{7} & $\mathrm{~L}$ & 18 & 15 & 8 & 8 \\
\hline & $\mathrm{S}$ & 18 & 17 & 7 & 8 \\
\hline \multirow[t]{2}{*}{8} & $\mathrm{~L}$ & 14 & 19 & 6 & 8 \\
\hline & $\mathrm{S}$ & 21 & 22 & 8 & 9 \\
\hline
\end{tabular}

1) $\mathrm{L}$ : The long survival line, $\mathrm{S}:$ The short survival

surface scar appeared at the graft site.

The observation period was changed at stages of the selection, i.e., from the first to the fourth generation, grafts were observed on days 5 to 30 ; on days 5 to 45 for the fifth generation; on days 5 to 60 for the sixth generation; and on days 5 to 90 for the seventh and eighth generations, because of delayed graft rejection at the later generations in the $\mathrm{L}$ line.

\section{Graft-versus-host reaction and immune response}

GVHR competence was measured by the splenomegaly assay. The method of GVHR had been previously presented by AshiKaga et al. ${ }^{14)}$. The degree of GVHR was expressed as an index called splenomegaly index (SI), which was calculated by the following formula :

SI=Spleen weight $/$ Embryo weight

Commercial fertilized eggs whose parents had not the $B^{11}$ allele were used as recipients of GVHR.

The immune competence in the $\mathrm{L}$ and $\mathrm{S}$ lines was compared at the fifth generation of chicks. Sheep red blood cells (SRBC) were used as antigen. One $\mathrm{m} l$ of $10^{8}$ cells $/ \mathrm{m} l$ of SRBC was injected into the wing vein at eight weeks-old chicks. The chicks were bled the 7th and 14th days after injection. Sera were inactivated at $56^{\circ} \mathrm{C}$ for 30 minutes and antibodies were determined by hemagglutination. 


\section{Results}

\section{Response to selection}

At the base population, 39 chicks received allografts from the $B$ compatible birds of the same population. The mean survival time of allografts was $18.7 \pm 4.3$ days. Birds showing a longer survival time than the mean were selected as the $\mathrm{L}$ line and birds having shorter days than the mean were selected as the $\mathrm{S}$ line. From the first generation, the selection was carried out in each line with a selection intensity of about $50 \%$.

The results of two-way selection for the survival time of allografts are shown in Fig. 1 and Table 2. Although the population size was small, the selection in the L line was very effective. Namely, the mean survival time of allografts became gradually longer with each successive generation of selection. In the $S$ line, however, the effect of selection was not observed. The graft survival time became slightly even longer in the later generations, contrary to the expectation. Line differences were significant for each generation of selection with the exception of the second generation (Fig. 2).



Fig. 1. Mean survival time of grafts in the $\mathrm{L}$ and $\mathrm{S}$ lines selected for long and short survival time. ${ }^{*} \mathrm{P}<0.05 ;{ }^{* *} \mathrm{P}<0.01$.

Table 2. Mean survival time of grafts at each generation (days)

\begin{tabular}{cccccc}
\hline \hline \multirow{2}{*}{ Generation } & \multicolumn{2}{c}{ L line } & & \multicolumn{2}{c}{ S line } \\
\cline { 2 - 3 } \cline { 5 - 6 } & Tested & Selected & & Tested & Selected \\
\hline 0 & 18.77 & 22.37 & & 18.77 & 14.88 \\
1 & 19.75 & 23.00 & & 17.10 & 14.67 \\
2 & 19.45 & 22.70 & & 17.71 & 15.67 \\
3 & 22.28 & 25.83 & & 18.95 & 16.52 \\
4 & 25.91 & 28.12 & & 18.28 & 17.00 \\
5 & 39.48 & 47.26 & & 24.00 & 22.31 \\
6 & 55.70 & 81.11 & & 29.87 & 23.65 \\
7 & 69.33 & 79.75 & & 34.54 & 25.13 \\
8 & 86.94 & & 34.72 & \\
\hline
\end{tabular}


At the eighth generation of selection, the difference between the $\mathrm{L}$ and $\mathrm{S}$ line was 52.2 day.

The selection differential, selection response and realized heritability are shown in Table 3. For calculating these parameters, the logarithmic transformation of the mean survival time was carried out, so as to obtain a normal distribution. Since no control population was set in this experiment, the response to selection was determined from the difference between the $L$ and $S$ lines. The selection responses showed fairly constant values with the exception of the second generation of selection. The realized heritabilities were comparatively high, with a mean value of 0.33 .

Survival of allografts from different donors

The experiment was designed to test whether the mean survival time of allografts for the $\mathrm{L}$ line would retain a longer time than that of the $\mathrm{S}$ line when the grafts of different donors were used. The GVHR line with the same $B$ genotype as in the $\mathrm{L}$ and $S$ lines was used as donors. The mean survival time of allografts and percent of survival allografts at 90 days after grafting are shown in Table 4. The mean survival time was 42.6 days for GVHR $\rightarrow \mathrm{L}$ allografts and was 31.6 days for GVHR $\rightarrow \mathrm{S}$

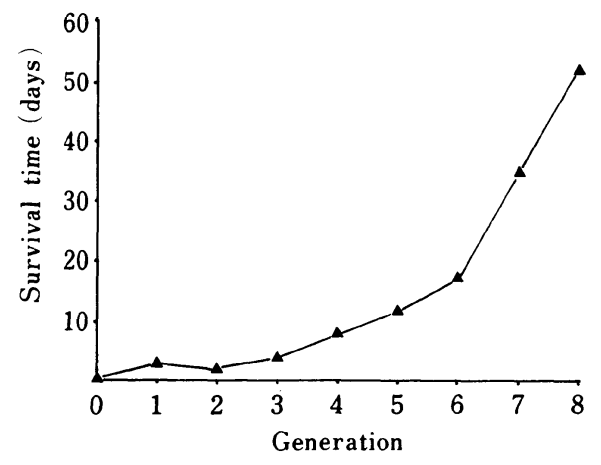

Fig. 2. Line differences (L-S line) during the course of selection.

Table 3. Selection differentials and responses estimated from line differences

\begin{tabular}{cccc}
\hline \hline Generation & $\begin{array}{l}\text { Selection } \\
\text { differential }\end{array}$ & $\begin{array}{l}\text { Selection } \\
\text { response }\end{array}$ & $\begin{array}{l}\text { Realized } \\
\text { heritability }\end{array}$ \\
\hline 1 & $0.1771^{11}$ & $0.0626^{11}$ & 0.353 \\
2 & 0.1327 & -0.0219 & -0.165 \\
3 & 0.1203 & 0.0296 & 0.246 \\
4 & 0.1238 & 0.0812 & 0.656 \\
5 & 0.0671 & 0.0647 & 0.964 \\
6 & 0.1098 & 0.0545 & 0.496 \\
7 & 0.2646 & 0.0320 & 0.121 \\
8 & 0.1989 & 0.0960 & 0.483 \\
Total & 1.1943 & 0.3987 & 0.334 \\
\hline
\end{tabular}

1) Expressed logarithmically. 
Table 4. Mean suvival time and survival percent of grafts from different donor lines in the $\mathrm{L}$ and $\mathrm{S}$ lines at the 7 th generation

\begin{tabular}{ccccc}
\hline \hline Donor & Recipient & $\begin{array}{l}\text { No. of } \\
\text { birds }\end{array}$ & $\begin{array}{l}\text { Mean survival } \\
\text { time (days) }\end{array}$ & $\begin{array}{l}\text { Percent of survival } \\
\text { graft (for 90 days) }\end{array}$ \\
\hline L & L & 33 & $69.33 \pm 23.59^{\mathrm{a}}$ & $48.48^{\mathrm{a}}$ \\
L & $\mathrm{S}$ & 35 & $34.54 \pm 14.52^{\mathrm{b}}$ & $0.00^{\mathrm{b}}$ \\
GVHR & $\mathrm{L}$ & 24 & $42.62 \pm 26.07^{\mathrm{bc}}$ & $12.50^{\mathrm{b}}$ \\
GVHR & $\mathrm{S}$ & 25 & $31.64 \pm 20.04^{\mathrm{b}}$ & $4.00^{\mathrm{b}}$ \\
S & $\mathrm{S}$ & 26 & $54.77 \pm 26.78^{\mathrm{c}}$ & $26.92^{\mathrm{ab}}$ \\
\hline
\end{tabular}

$a, b, c$ Means within columns not sharing a common superscript are significantly different $(\mathrm{P}<0.01)$.

allografts. The difference between these two means was not significant statistically. ln the recipients of the $\mathrm{L}$ line, the mean survival time for $\mathrm{L} \rightarrow \mathrm{L}$ and GVHR $\rightarrow \mathrm{L}$ combinations showed the values of 69.3 and 42.6 days, respectively. The difference between these two values was statistically significant $(P<0.01)$. In the $S$ line recipients, the difference of mean survival time between $S \rightarrow S$ and GVHR $\rightarrow S$ combinations was also significant, although the difference was not observed between $\mathrm{L}$ $\rightarrow \mathrm{S}$ and GVHR $\rightarrow \mathrm{S}$ combinations.

Of the 33 allografts in the combination of $\mathrm{L} \rightarrow \mathrm{L}, 16$ grafts $(48.5 \%)$ had survived over 90 days, while only $12.5 \%$ of allografts in the combination of GVHR $\rightarrow \mathrm{L}$ had survived for 90 days. However, the difference in the survival rate between the GVHR $\rightarrow \mathrm{L}$ and GVHR $\rightarrow \mathrm{S}$ combinations was small and not significant.

Correlated responses in competences of graft-versus-host reaction and immune response

In the seventh generation of selection, both of the $\mathrm{L}$ and $\mathrm{S}$ lines were tested to compare the donor competence in GVHR. The average SI of the L line was 6.10, and that of the $\mathrm{S}$ line was 4.55 (Table 5). The line difference was highly significant statistically.

Antibody responses against SRBC were determined at one and two weeks after injection of antigen (Table 6). There was no significant difference between the $\mathrm{L}$ and $\mathrm{S}$ lines.

\section{Discussion}

Most of works about skin grafting have been done with the purpose to check the homogeneity and/or the heterogeneity of populations ${ }^{8,15,16)}$. However, selection works for the survival time of skin allografts are only a few ${ }^{17,18)}$. In the present study, selection for the long and short survival time of allografts within the same major histocompatibility genotype of chicks was carried out to establish two lines with different alleles at the minor histocompatibility loci.

In inbred lines having the $B$ genotype identity, the mean survival time of allografts was quite long, usually more than 120 days ${ }^{15,17)}$. However, the mean survival time of allografts applied to non-inbred birds is not so long. In the present study the mean survival time in the base population was 18.8 days. This result 
Table 5. Mean splenomegaly indices of embryos inoculated with lymphocytes from the $\mathrm{L}$ and $\mathrm{S}$ lines

\begin{tabular}{cccc}
\hline \hline Line of donor & Male & Female & Mean \\
\hline $\mathrm{L}$ & $5.586 \pm 2.219^{\mathrm{a}}$ & $6.681 \pm 1.518$ & $6.099 \pm 1.869^{* *}$ \\
& $(17)^{\mathrm{b}}$ & $(15)$ & $(32)$ \\
$\mathrm{S}$ & $4.443 \pm 1.983$ & $4.682 \pm 1.561$ & $4.550 \pm 1.773$ \\
& $(22)$ & $(18)$ & $(40)$ \\
\hline
\end{tabular}

a) Mean \pm S. D.

b) Number of birds tested.

${ }^{* *}$ Line difference is significant at $\mathrm{P}<0.01$.

Table 6. Anti-SRBC titer of chickens in the $\mathrm{L}$ and $\mathrm{S}$ lines

\begin{tabular}{cccccc}
\hline \multirow{2}{*}{ Line } & \multicolumn{2}{c}{$\begin{array}{c}\text { One week after } \\
\text { injection }\end{array}$} & & \multicolumn{2}{c}{$\begin{array}{c}\text { Two weeks after } \\
\text { injection }\end{array}$} \\
\cline { 2 - 3 } \cline { 5 - 6 } \cline { 5 - 6 } & Male & Female & & Male & Female \\
\hline $\mathrm{L}$ & $\begin{array}{c}5.75 \pm 0.95^{\mathrm{a}} \\
(4)^{\mathrm{b}}\end{array}$ & $\begin{array}{c}5.20 \pm 1.65 \\
(5)\end{array}$ & & $\begin{array}{c}4.00 \pm 1.41 \\
(4)\end{array}$ & $\begin{array}{c}3.80 \pm 1.30 \\
(5)\end{array}$ \\
$\mathrm{S}$ & $\begin{array}{c}5.40 \pm 1.14 \\
(5)\end{array}$ & $\begin{array}{c}5.25 \pm 1.71 \\
(4)\end{array}$ & & $\begin{array}{c}3.60 \pm 1.34 \\
(5)\end{array}$ & $\begin{array}{c}3.75 \pm 1.26 \\
(4)\end{array}$ \\
\hline
\end{tabular}

a) Mean \pm S. D.

b) Number of birds tested.

suggests that minor histocompatibility loci have fairly affected the survival time of allografts.

In the present study, although the selection for the long survival time of allografts was very effective, the mean survival time of allografts in the $S$ line did not decrease. Since the size of selected population was very small, it seemed that selection against the survival time of allografts might bring about homozygosity in some minor histocompatibility loci, and consequently lead to the increase of the survival time of allografts. However, as shown in Table 4, the mean survival time for $\mathrm{L} \rightarrow \mathrm{L}$ allografts was significantly longer than that of $S \rightarrow S$ allografts. This result suggests that the degree of segregation at the minor histocompatibility loci is still higher in the S line than in the $\mathrm{L}$ line.

Although it is well known that the difference of major histocompatibility antigens affect the degrss of splenomegaly in GVHR ${ }^{19-21)}$, only a few works have been reported about the effects of minor histocompatibility on $\mathrm{GVHR}^{22,23)}$. In the present study, it is also evident that antigenic differences controlled by alleles at minor histocompatibility loci affect the degree of splenomegaly.

\section{References}

1) Schierman, L.W. and A.W. Nordskog (1961) Relationship of blood type to histocompatibility in chickens. Science, $134: 1008-1009$.

2) Craig, J.V. and E.M. McDermid (1963) Prolonged skin homograft survival and 
erythrocyte (B-locus) antigen in young chicks. Transplantation, 1: 191-200.

3) Gilmour, D.G. (1963) Strong histocompatibility effects associated with the B-blood group system of chickens. Heredity, 18: 123.

4) Schierman, L.W. and A.W. Nordskog (1965) Evidence for a second blood group histocompatibility sistem in chickens, Transplantation, $3: 44-48$.

5) Bacon, L.D. and J.V. Craig (1966) Evidence for a histocompatibility locus on the W chromosome in chickens. Poult. Sci., $45:$ 1066-1067.

6) Bacon, L.D. and J.V. Craig (1969) Variability of response to female histocompatibility antigen in chickens. Transplantation, $7: 387-393$.

7) Gilmour, D.G. (1967) Histocompatibility antigen in the heterogametic sex in the chicken. Transplantation, $5:$ 699-706.

8) Hála, K. (1969) Syngeneic lines of chickens. III. The number of different histocompatibility loci between the lines. Folia Biol., $15:$ 136-140.

9) FrENCH, I.V. (1975) Histocompatibility of chickens homozygous at the $B$-locus matching on skin graft survival. J. Immunogenet., 2 : 171-178.

10) Yамамото, Y. (1975) Relationship of $B$ blood group locus to skin allograft in chickens. Anim. Blood Grps. Biochem. Genet., 6 : 19-24.

11) Okada, I. and H. Mikami (1974) Three generations of selection for high and low donor competences of splenomegaly in chickens. Br. Poult. Sci., 15 : 1-10.

12) Purchase, H.G. (1967) A method for multiple skin grafting. Poult. Sci., 46 : 1017-1019.

13) Polley,C.R., A.E. Grosse and J.V. Craig (1960) Skin-grafting technique for use in genetic studies with chichens. Transplant. Bull., $7: 425-428$.

14) Ashikaga, M., I. OKada, Y. Yamamoto and H. Matsuda (1984) Interaction of the GVHR-selected lines and the $B$ genotypes in the genetic resistance to Marek's disease. Jpn. Poult. Sci., 21 : 102-110.

15) Bacon, L.D. and J. MotTA (1982) Skin-graft histocompatibility within Regional Poultry Research Laboratory inbred chicken line. Poult. Sci., 61 : 218-220.

16) Bacon, L.D., N.Ismail and J.V. MotTA (1987) Allograft and antibody response of $15 \mathrm{I}_{5}-B$ congenic chickens. Avian Immunology (Weber, W.T. and D.L. EwERT, eds.) : 219-233. Alan R. Liss, Inc., N.Y.

17) Hašek, M., F. Knízetová and H. Mervartová (1966) Syngeneic lines of chickens. I. Inbreeding and selection by means of skin grafts and tests for erythrocyte antigens in C line chickens. Folia Biol., 12:335-342.

18) Hála, K., M. Hašek, I. HložÁnek, J. Hort, F. Knízetová and H. Mervartová (1966) Syngeneic lines of chickens. II. Inbreeding and selection within the M, W and I lines and crosses between the C, M and W lines. Folia Biol., 12: 407-422.

19) JAFFe, W.P. and E.M. McDeRmid (1962) Blood groups and splenomegaly in chick embryos. Science, $137: 984$.

20) Schierman, L.W. and A.W. Nordskog (1963) Influence of the $B$ blood group histocompatibility locus in chickens on a graft-versus-host reaction. Nature, 197 : 511-512.

21) Mikami, H., I. Okada and Y. Hachinohe (1969) Genetic differences in the homologous splenomegaly in chickens due to the donor. Jpn. J. Genet., 44 : 81-87.

22) Longenecker, B.M., F. Pazderka, G.R.J. Law and R.F. Ruth (1973) The graftversus-host reaction to minor alloantigens. Cell. Immunol. $8: 1-11$.

23) Yамамото, Y. (1981) The quantitative effects of the $B$ blood group locus and sex linked histocompatibility antigen in chickens on $\mathrm{G}-\mathrm{v}-\mathrm{H}$ reaction. Poult. Sci., 60 : $2567-2570$. 


\title{
鶏における同種移植片の生着期間に対する二方向選抜
}

\author{
山本義雄・岡田育穂 \\ 広島大学生物生産学部，東広島市 724
}

䳕の同種移植片の生着期間について二方向選抜を 8 世 代にわたり行った。選抜用の基礎集団は主要組織適合 $B$ 遺伝子型が $B^{11} B^{11}$ のもののみで構成された。生着期間 について長 $(\mathrm{L})$ ，短 $(\mathrm{S})$ いずれの方向に選抜した系統 に対しても，移植片の供与系統としては L 系統を用い た。

L 系統における選抜は有効であったが， S 系統では 必ずしも有効ではなかった。 L・S 両系統間の差は選抜 世代の経過と共に拡大した。両系統間の差で求めた実現 遺伝率は 0.334 であった。選抜 7 世代目において，同種
移植後 90 日目における移植片の生着率はL 系統で 48.5

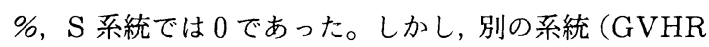
系）を供与系統として用いると， L・S 両系統における 生着率はそれぞれ 12.5 及び $4.0 \%$ であった。選抜によ る移植片対宿主反応能及び免疫応答能への相関反応を調 べた結果，移植片対宿主反応能にのみ有意な系統差が観 察された。

（家禽会誌，27：337～345，1990） キーワード: 組織適合性, 肉髯移植, 皮唐移植, 選抜, 移植片対宿主反応 